
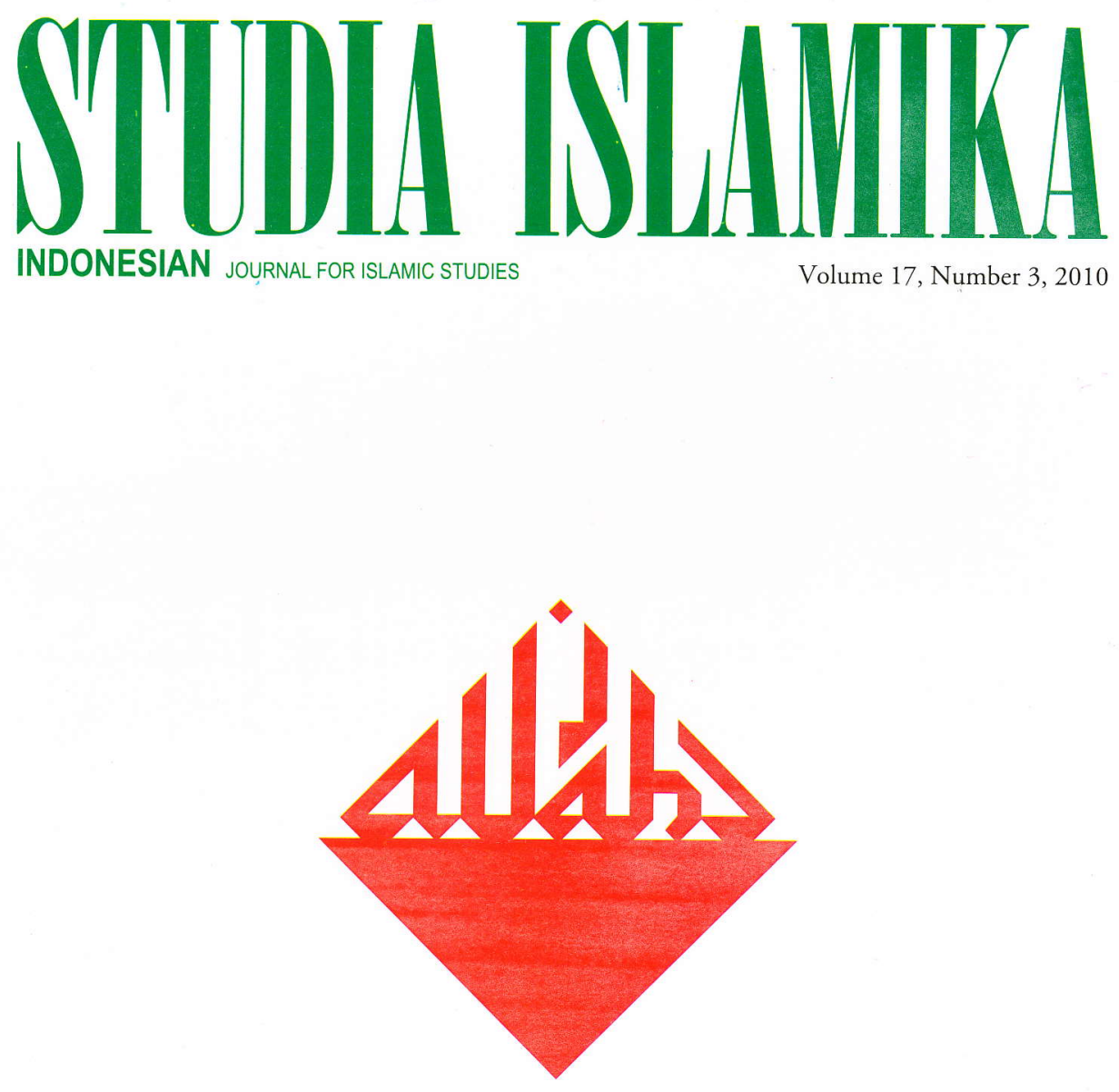

THE ELITIST PREMISES OF

SnOUCK Hurgonje'S Association Fantasy

Kees van Dijk

The Shaving of The Prophet's Hair (NABI APARAS):

The Philology of Lombok TeXts

Dick van der Meij

RELIGION AND DIALOGUE IN INDONESIA:

From the SOEHARTO PERIOD TO THE PRESENT

Mujiburrahman 


\section{EDITORIAL BOARD:}

M. Quraish Shihab (UIN Jakarta)

Taufik Abdullah (LIPI Jakarta)

Nur A. Fadhil Lubis (IAIN Sumatra Utara)

M.C. Ricklefs (National University of Singapore)

Martin van Bruinessen (Utrecht University)

John R. Bowen (Washington University, St. Louis)

M. Atho Mudzhar (UIN Jakarta)

M. Kamal Hasan (International Islamic University, Kuala Lumpur)

M. Bary Hooker (Australian National University, Australia)

Virginia Matheson Hooker (Australian National University, Australia)

\section{EDITOR-IN-CHIEF}

Azpumardi Azra

\section{EDITORS}

Jajat Burbanudin

Saiful Mujani

Jambari

Fu'ad Jabali

Oman Fathurabman

\section{ASSISTANT TO THE EDITORS}

\section{Testriono}

Setyadi Sulaiman

\section{ENGLISH LANGUAGE ADVISOR}

Dina Afrianty

Dick van der Meij

\section{ARABIC LANGUAGE ADVISOR}

Abmadi Rojali

\section{COVER DESIGNER}

\section{S. Prinka}

STUDIA ISLAMIKA (ISSN 0215-0492) is a journal published by the Center for the Study of Islam and Society (PPIM) UIN Syarif Hidayatullah, Jakarta (STT DEPPEN No. 129/SKIDITJEN/PPG/STT/1976). It specializes in Indonesian Islamic studies in particular, and South-east Asian Islamic Studies in general, and is intended to communicate original researches and current issues on the subject. This journal warmly welcomes contributions from scholars of related disciplines.

All articles published do not necessarily represent the views of the journal, or other institutions to which it is affliated. They are solely the views of the authors. The articles contained in this journal have been refereed by the Board of Editors. 


\section{Document}

\section{Focused Group Discussion (FGD) on the Role of Muslim-Based Organization (MBO) in Contemporary Indonesia}

\section{Asep Saepudin Jahar}

$\mathrm{I}$

n December 2010, Center for the Study of Islam and Society (Pusat Pengkajian Islam dan Masyarakat, PPIM) UIN Syarif Hidayatullah

Jakarta in cooperation with The Asia Foundation (TAF) conducted a Focus Group Discussion (FGD) with several Muslim-Based Organizations (MBO) in five major cities in Indonesia: Padang (West Sumatra), Yogyakarta (DI Yogyakarta), Surabaya (East Java), Makassar (South Sulawesi), and Mataram (West Nusa Tenggara, NTB). The FGD is designed to gain additional information on the role of $\mathrm{MBO}$ or Islamic civil society organizations in Indonesia following a quantitative survey conducted by PPIM, TAF, and Indonesian Survey Institute (LSI).

The five targeted cities were chosen based on several reasons. First, these cities were chosen because MBO such as Nahdlatul Ulama (NU) in East Java and Muhammadiyah in Yogyakarta have played significant roles in the socio-political development. Second, some of the cities such as Padang and Mataram are homes for other MBOs: the Persatuan Tarbiyah Islam (Perti) and Nahdlatul Wathon (NW).

The general aim of this FGD is to analyze the roles of MBOs in Indonesia and the participation of MBOs in the socio-political development of the society. To obtain in-depth qualitative data, the FGD is focused on the two largest MBOs in Indonesia: NU and Muhammadiyah. This is because to the present, the two MBOs represent two mainstreams of Indonesian Islam: modernist and tradisionalist. The FGD also looked at other MBOs which develop in certain cities, such as Perti in Padang and NW in Mataram. These two MBOs are, in fact, traditionally close to NU. 
The NU has a strong basis in rural areas, especially in pesantren. In addition, Muhammadiyah gains strong support in urban areas. Muhammadiyah focuses their activities on developing schools, hospitals, and other public services. The roles of these MBOs have been the main concerns of international donors due to the importance of their activities in Indonesia's socio-political development. It is also assumed that community development requires the cooperation of both the government and nongovernments organizations. In addition, the FGD also attempted to reveal MBO's political engagement at the local politics and to uncover how far they have engaged with issues such as of good governance and transparency.

In every city, the FGD was attended by 10 participants who are activists from NU or Muhammadiyah, and Perti in Padang and NW in Mataram. A balanced gender representation is highly considered for this FGD to generate better information on issues relevant to our objectives.

\section{Political Engagement}

NU and Muhammadiyah remain the major actors in Indonesia's sociopolitical development. Based on previous surveys, it is clear that the sociopolitical roles of NU and Muhammadiyah are very important for political mobilization, including to develop citizen awareness and in empowering the community in education and health. These roles are mostly carried out through the MBOs activities and programs such as the regular pengajian (Qur'anic recitation) activities.

In terms of the work of MBOs and the local government, it is revealed that the local government has been actively included MBOs in the local development process. The role of $\mathrm{MBO}$ s has become imminent in places where government has limited access to the community. In addition, NU with its women's wing organization, Fatayat, and Muhammadiyah with Aisyiyah have also played significant roles in empowering women and improving the quality of health services and education.

The roles of NU and Muhammadiyah in terms of Indonesia's political development are also significant. Democracy, human rights, gender mainstreaming have become part of NU and Muhammadiyah major focus. In terms of political engagement, NU relied on the strength of pesantrens, through the communal bond of its proponents, and the roles of the charismatic religious figures (kiailtuan guru). 
The FGD also questions the specific roles of NU and Muhammadiyah at the local government. Related to this, the FGD questioned how MBOs interact with the local government and what roles they have in local political development. The works of the two MBOs are also explored to see how the cooperation is developed during this time. One of the important issues raised in the FGD was how MBOs influence the public policy making such as in local budgeting.

Overall, the FGD provides important information on the involvement of NU and Muhammadiyah in Indonesian politics and in implementing good governance in contemporary Indonesia. The important role of these MBOs will continue to strengthen the process of Indonesia's democracy. In addition, NU and Muhammadiyah and some other Islamic organizations have acted as catalyst for Indonesia's socio-political transformation, by promoting the spirit of nationalism. Thus, strengthening democracy through the involvement of NU and Muhammadiyah and other civil society organizations in socio-political development will continue to be important strategies that still need to be used until now.

Asep Saepudin Jahar is a researcher at PPIM UIN Jakarta 